\title{
A NEW RECORD AND A REDESCRIPTION OF PoLyPEDILUM PRUINA FREEMAN (DIPTERA: CHIRONOMIDAE) WITH A KEY TO INDIAN SPECIES ASSOCIATED WITH RICE FIELDS
}

\author{
Sailesh Chattopadhyay
}

Faculty of Forestry, Birsa Agricultural University, Kanke, Ranchi, Bihar 834006, India

\begin{abstract}
Polypedilum pruina Freeman is recorded for the first time from the rice paddy area of India and redescribed in light of modern taxonomic usages. A new dichotomous key to rice field species of genus Polypedilum Kieffer is also presented.
\end{abstract}

\section{Key Words}

Polypedilum, Chironomidae, Diptera

\begin{tabular}{|c|c|}
\hline \multicolumn{2}{|c|}{ Abbreviations } \\
\hline An - Anal vein & AR - Antennal ratio \\
\hline $\mathrm{BR}$ - Bristle ratio & BV - Beinverhaltnisse \\
\hline C - Costa & CA - Head antennal ratio \\
\hline CP - Head palpal ratio & $\mathrm{FCu}$ - Cross vein of wing \\
\hline $\mathrm{Fe}-\mathrm{Femur}$ & HR - Hypopygium ratio \\
\hline HV - Hypopygium value & IV - Inner vertical setae of vertex \\
\hline LR - Leg ratio & $\mathrm{L} / \mathrm{W}$ - Palpal ratio \\
\hline OV - Outer vertical setae of vertex & PO - Post ocular setae of vertex \\
\hline R - Radius & $\mathrm{R}_{1}$ - Wing vein \\
\hline $\mathrm{R}_{2+3}$ - Wing vein & $\mathrm{R}_{4+5}$ - Wing vein \\
\hline $\mathrm{R}_{5}^{2+3}$ Cell of wing & RM - Cross vein of wing \\
\hline SV - Schenkel - Schiene - Verhaltnisse & $\mathrm{ta}_{1}-\mathrm{ta}_{5}-$ Tarsomeres \\
\hline
\end{tabular}

\section{Introduction}

Rice fields have long been recognised as a pre-eminent habitat for chironomids (Diptera: Chironomidae) and genus Polypedilum Kieffer is one of the most common and widespread genera having a fairly wide latitude of ecological tolerance (Hashimoto et al. 1981; Sasa \& Kikuchi, 1986; Chattopadhyay et al. 1988; Chaudhuri \& Chattopadhyay 1990).

The genus Polypedilum Kieffer has so far been described in ten species viz. P. aegyptium Kieffer, $P$. annulatipes (Kieffer), $P$. ascium Chaudhuri, Guha \& Das Gupta, $P$. chaudhurii Chaudhuri, Guha \& Das Gupta, $P$. circulum Chaudhuri \& Chattopadhyay, $P$. lineatum Chaudhuri, Guha \& Das Gupta, $P$. nubifer (Skuse), $P$. medivittatum Tokunaga, $P$. suturalis (Johannsen), P. yapensis

Received 3 May 1999;
Tokunaga (Chaudhuri \& Chattopadhyay, 1990). Of these Indian rice field species, three species (P. nubifer, $P$. suturalis and $P$. yapensis have been reported from the rice fields of Thailand (Hashimoto et al., 1981) and one species, P. nubifer from Japan (Sasa \& Kikuchi, 1986). Besides, 31 species of genus Polypedilum are known from India other than the rice field (Chaudhuri \& Guha, 1987)

The present paper deals with one new record, Polypedilum pruina Freeman with detail description and illustration. A key of rice field chironomids of the genus Polypedilum Kieffer is also given in this paper.

Adults were collected by sweeping in the rice field of Birsa Agricultural University campus, Ranchi $\left(23^{\circ} 18^{\prime} \mathrm{N}, 8^{\circ} 19^{\prime} \mathrm{E}\right.$; Alt. $625 \mathrm{~m}$.), Bihar, India. Phenol-balsam technique as used by Das 
Gupta and Wirth (1968) was followed for microslide preparation of adults. The general morphology and terminology follow Saether (1980) and, Chaudhuri and Chattopadhyay (1987). Measurements are given in millimeter $(\mathrm{mm})$, the mean value is followed by the range and sample size (n) in parentheses.

The material studied is at present in the Faculty of Forestry, Birsa Agricultural University, Ranchi and will be deposited in the National Zoological Collections at Zoological Survey of India, Calcutta in due course.

\section{Polypedilum pruina Freeman (Figs 1-3)}

1954: 179; 1955: 376; 1958: 280-281.

\section{Material examined}

8 males, Bihar, Ranchi (Birsa Agricultural University campus), 24 .viii.1998, Coll. S. Chattopadhyay.

\section{Diagnostic features}

Adult: Male. Body $1.93(1.90-1.94, \mathrm{n}=8)$ long, wing $1.05(1.05$ $1.06, \mathrm{n}=8)$ long and $0.35(0.33-0.35, \mathrm{n}=8)$ wide.

Head: Brown. Vertex with 13-14 setae (IV 4-5, OV 7 and PO 2-3), corona bare. Clypeus with 19-21 setae, clypeal ratio 0.84 Maxillary palp light brown, ratio of palpomeres length I-V: 9:8:23:23:28. L/W 4.80. Eyes reniform without dorsal extension. Frontal tubercles absent. Antennae brown, ratio of flagellomere length I-XIII: 8:6:7:7:6:7:7:7:7:7:7:7:108:, AR 1.30. Pedicel ratio 1.62. CA 0.62, CP 1.18 .

Thorax: Brown. Antepronotum thin and with slight emargination in the middle, antepronotals 0. Mesonotum brown. Acrostichals $18-19$, uniserial, dorsocentrals 15-17, irregularly biserial, humerals two, prealars 4-6. Scutellum with 20 setae in two transverse rows; postscutellum dark brown and bare.

Wing: (Fig. 1) Hyaline. Brachiolum with one seta and 18-20 sensilla campaniformia, $\mathrm{R} 15-16, \mathrm{R}_{1} 16-17$ and $\mathrm{R}_{4+5}$ with 21 setae; $\mathrm{R}_{2+3}$ meets $\mathrm{C}$ at a distance of 0.07 from $\mathrm{R}_{1}, \mathrm{RM}$ pale brown and proximal to $\mathrm{FCu}$. An ends slightly proximal to $\mathrm{FCu}$. Squama with nine setae. Haltere light brown with 6-8 setae.

Legs: Yellow. Fore tibia with a blunt, slightly attenuated scale bearing two long setae at its base. Mid tibia (Fig. 2) with single spur, hooked apically, 0.01 long, ratio of length of spur to the apical diameter of mid tibia 11:10; hind tibia with single spur, 0.01 long, ratio of length of spur to the apical diameter of hind tibia 12:10. Tarsomeres III and IV pale brown. Pulvilli small.

Proportion and ratios of leg segments

\begin{tabular}{llllllllllll}
\hline & $\mathrm{Fe}$ & $\mathrm{Ti}$ & $\mathrm{ta}_{1}$ & $\mathrm{ta}_{2}$ & $\mathrm{ta}_{3}$ & $\mathrm{ta}_{4}$ & $\mathrm{ta}_{5}$ & LR & BV & SV & BR \\
\hline Fore & 36 & 23 & 41 & 25 & 20 & 15 & 9 & 1.78 & 1.44 & 1.34 & 3.40 \\
Mid & 41 & 38 & 25 & 14 & 11 & 11 & 5 & 1.78 & 2.53 & 3.22 & 2.71 \\
Hind & 38 & 32 & 18 & 10 & 7 & 7 & 3 & 1.80 & 3.25 & 4.11 & 2.57 \\
\hline
\end{tabular}
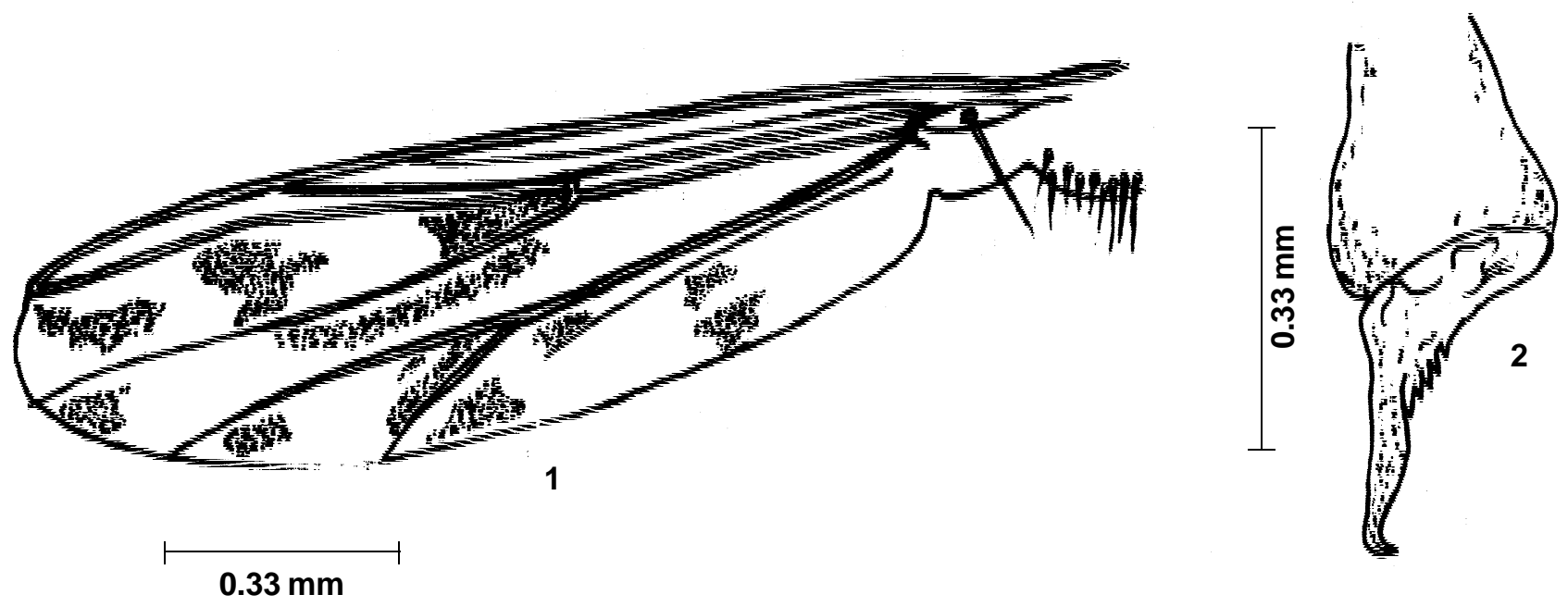

Figures 1 - 2. Polypedilum pruina Freeman. 1. Wing; 2. Mid tibial spur 


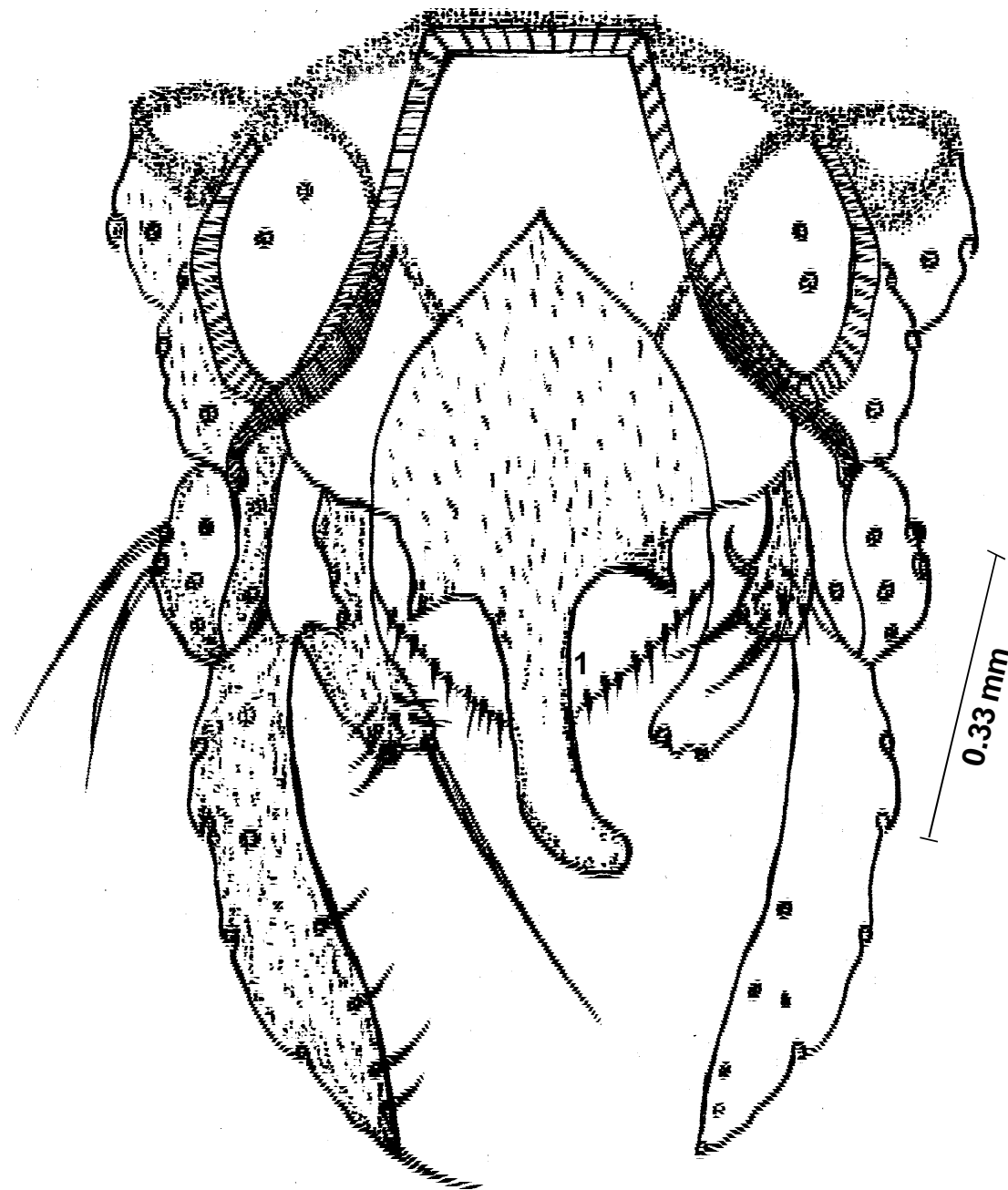

Figure 3. Male hypopygium of Polypedilum pruina Freeman

Abdomen: Brown. Anal point of male hypopygium (Fig. 3) broad, downturned and with lateral teeth basally of variable length giving a trilobed appearance and with 7-8 basolateral setae. Gonocoxite with 12-13 long setae; gonostylus long slightly attenuated and with one long seta at seta at apex and four setae in its inner apical margin and 10-12 setae over it. Superior volsella with two long inwardly directed pointed setae, a curved seta and 4-6 setae over it. Inferior volsella long elongated, little bowed in apex and with one long seta at apex and 8-10 incurved setae near apex. Transverse sternapodeme 0.06 , lateral sternapodeme 0.03 , coxapodeme 0.04 , and phallapodeme 0.04 long. HR 0.60 ; HV 2.41.

\section{Female: Unknown.}

Remark: Polypedilum pruina was first described by Freeman in 1954 from Cape Province. This species is separated from all other species of genus Polypedilum by the following combination of characters: (i) frontal tubercles absent, (ii) scutellum with 20 setae in two transverse rows, (iii) wing with three spots in cell $R_{5}$ (iv) haltere setose, (v) mid tibial spur hooked apically, and (vi) anal point with lateral teeth basically, giving a trilobed appearance.

\section{Acknowledgements}

The author is grateful to Dr. P.K. Chaudhuri, Department of Zoology, University of Burdwan, West Bengal, for kindly going through the manuscript and for his valuable suggestions. Sincere thanks are due to Mrs. Soma Chattopadhyay for technical assistance.

\section{References}

Chattopadhyay, S., T. Datta and P.K. Chaudhuri (1988). Morphology and biology of Polypedilum nubifer (Skuse) from India (Diptera: Chironomidae) J. Beng. Nat. Hist. Soc., 7(2): 29-41.

Chaudhuri, P.K. and S. Chattopadhyay (1987). Life stages of Glyptotendipes barbipes (Staeger) with a brief account of silk spinning by the larvae Acta. Biol. Par.,16: 15-29.

Chaudhuri, P.K. and S. Chattopadhyay (1990). Chironomids of the rice paddy areas of West Bengal, India (Diptera: Chironomidae) Tijdschr. Ent., 133(2): 149-195.

Chaudhuri, P.K. and D.K. Guha (1987). A conspectus of chironomid midges (Diptera: Chironomidae) of India and Bhutan Ent. Scand. suppl. 29: 23-33.

Das Gupta, S.K. and W.W. Wirth (1968). Revision of Oriental species of Stilobezzia Kieffer (Diptera: Ceratopogonidae) Bull. U.S. Nat. Mus., 283: 1-164.

Freeman, P. (1954). Chironomidae (Diptera) from Western Cape 
Province - IV., Proc. R. ent. Soc. London, 23: 172-180.

Freeman, P. (1955). Diptera (Nematocera) -Chironomidae S. Afr. Animal life, Uppsala, 2: 361-381.

Freeman, P. (1958). A study of the Chironomidae (Diptera) of Africa south to Sahara Bull. Br. Mus.nat. Hist. Ent., 6: 263-363.

Hashimoto, H., T. Wongsiri, N. Wongsiri, C. Tirawat, A. Lewvanich and K. Yasumatsu (1981). Chironominae from rice fields of Thailand with description of 7 new species. Tech, Bull. Taxonomy Br., Entomol- ogy \& Zoology Division, Department of Agriculture, Bangkok 7: 1-47. Saether, O.A. (1980). Glossary of chironomid morphology, terminology (Diptera: Chironomidae) Ent. Scand. Suppl. 14: 1-51.

Sasa, M. and M. Kikuchi (1986). Notes on the chironomids midges of the subfamilies Chironomidae and Orthocladiinae collected by light traps in a rice paddy areas in Tokushima (Diptera: Chironomidae) Japan J. Sanit. Zool. 31: 93-102.

\section{Key to the rice field species of Genus Polypedilum Kieffer in India}

1. Wing with spots or markings

1A. Wing without spots or markings

2. AR less than 1 P. lineatum Chaudhuri, Guha \& Das Gupta

2A. AR more than 1 3

3. Frontal tubercles present P. nubifer (Skuse)

3A. Frontal tubercles absent 4

4. Anal point narrow with pointed apex P. annulatipes (Kieffer)

4A. Anal point broad without pointed apex .5

5. Scutellum with 1 row of setae P. aegyptium Kieffer

5A. Scutellum with 2 rows of setae 6

6. Gonostylus straight P. chaudhurii Chaudhuri, Guha \& Das Gupta

6A. Gonostylus curved P. pruina Freeman

7.

Haltere setose 8

$7 \mathrm{~A}$.

Haltere bare .

8. Superior volsella curved with blunt tip and one long seta near the base P. circulum Chaudhuri \& Chattopadhyay

8A. Superior volsella scimitar - like without lateral seta and P. medivittatum Tokunaga

9. Superior volsella with out lateral seta P. ascium Chaudhuri, Guha \& Das Gupta

9A. Superior volsella with lateral setae. 10

10. Prescutellar present, Tergites with brown band P. suturalis (Johannsen)

10A. Prescutellar absent, Tergites uniformly brown ..P. yapensis Tokunaga 